\title{
IAMJ
}

INTERNATIONAL

AYURVEDIC

MEDICAL JOURNAL

\section{A REVIEW ARTICLE ON THE EFFICACY OF AYURVEDIC DRUGS IN THE MANAGEMENT OF MUTRAVEHA STROTAS}

\author{
Ritu $^{1}$, Kulbhushan ${ }^{2}$ \\ ${ }^{1}$ Assistant Professor in department of Dravyaguna Vigyana, at DBACH, Mandi Gobindgarh, Punjab, India \\ ${ }^{2}$ Professor in department of Swathvritta, at DBACH, Mandi Gobindgarh, Punjab, India
}

Corresponding Author: drrtsingh@gmail.com

\section{https://doi.org/10.46607/iamj2809092021}

(Published Online: September 2021)

Open Access

(C) International Ayurvedic Medical Journal, India 2021

Article Received: 12/08//2021 - Peer Reviewed: 30/08/2021 - Accepted for Publication: 31/08/2021

\section{Check for updates}

\begin{abstract}
Ayurveda an ocean of knowledge talks about almost every form of life. It suggests to us how to live and how to lives a healthy life. In Ayurveda, there is a vast knowledge of diseases and their management. Here we are discussing some drugs which are to be mentioned very much efficient in treating Urinary tract infections. Drugs like Punarnava, Goksuru, Kasa, etc. all having properties to treat this disease condition. By understanding the actions and properties of these we can use them either in a single form or can also make a formulation for treating such disorders. Here we conduct this review to give a small contribution to Ayurveda literature.
\end{abstract}

Keywords: Mutra Ashmarighna Dravya, Mutrasangrahaneeya Dravya, Mutravirajaneeya Dravya, Mutravirechaneeya Dravya, Urinary System, Herbs Etc.

\section{INTRODUCTION}

In the modern era, life is very hectic. Everyone is in the race of earning money only no one thinks about his body or mind. As Ayurveda states that healthy body makes a healthy mind, and a healthy body becomes by good eating habits. The things which we eat provide strength, nourishment, energy to our body. When we 
eat something, it goes through a lengthy process for consumption, absorption, excretion etc. The excretion of waste products is done with the help of an excretory system of the body. Waste products like water sodium, chloride, ions, amino acid, urea, uric acid are excreted through the body via urine. Mutraveha Strotas works on the urinary system. They help in nourishment, provide strength, helps in excretion, and give support to the organs of the system. Dravyas like Goksura, Kusa, Kasa, Ikshu etc. works on Mutraveha Strotas. ${ }^{1}$ These Dravyas act as Ashmarighna, Mutrasangrahneeya, ${ }^{2}$ Mutravirajaneeya, ${ }^{3}$ Mutravirechaneeya ${ }^{4}$ Mutral, ${ }^{5} \mathrm{Da}$ haprashmana ${ }^{6}$ etc. As Ayurveda believes to treat the disease condition or helps in the maintenance of health, we can wisely choose Ayurveda for the treatment of certain disease conditions which can be lifethreatening. These Dravyas can be used either in a single form or in a combination of other drugs. Dravyas having Snigdha-Laghu-Sheeta-Guna, Madhur-Rasa, Sheeta-Virya, Madhur-Vipaka are mostly working on
Mutraveha Strotas. Also, some Dravyas treat these infections by their Prabhav ${ }^{7}$ only. Here we compile all the properties, usage, and actions of these drugs together also try to conclude whether these drugs can be used single or can combine to make a proper formulation for these disorders.

\section{Aim \& Objectives}

- A literary review of drugs acting on Mutraveha Strotas.

- A literary review on the medicinal importance of these drugs.

\section{Material \& Methods}

- Importance of Ayurvedic drugs acting on Mutraveha Strotas from different Ayurvedic classical texts.

- A literary review on the other medical properties of these drugs in other diseased conditions.

\section{Introduction to Dravya's}

\begin{tabular}{|c|c|c|c|c|c|}
\hline $\begin{array}{l}\text { S. } \\
\text { No. }\end{array}$ & Dravya & $\begin{array}{l}\text { Sanskrit } \\
\text { Name }\end{array}$ & Botanical Name & Family & Synonyms \\
\hline 1. & Punarnava ${ }^{8}$ & Punarnava & $\begin{array}{l}\text { Boerhavia diffusa } \\
\text { Linn. }\end{array}$ & Nyctaginaceae & Shothghni, Spreading Hogweed \\
\hline 2. & $I k s h u^{9}$ & $I k s h u$ & $\begin{array}{l}\text { Saccharum } \quad \text { offix- } \\
\text { inarum Linn. }\end{array}$ & Gramineae & $\begin{array}{l}\text { Madhutrin, Ikha, Ganna, Dirgh- } \\
\text { chidra, Bhutirasa, Sugarcane }\end{array}$ \\
\hline 3. & Kusha ${ }^{10}$ & Kusha & $\begin{array}{l}\text { Desmostachya bipin- } \\
\text { nata Linn. }\end{array}$ & Gramineae & Suchiyagrh, Yagyabhusana \\
\hline 4. & Kasa ${ }^{11}$ & Kasa & $\begin{array}{l}\text { Saccharum sponta- } \\
\text { neum Linn. }\end{array}$ & Gramineae & Swetchamr, Thatch grass \\
\hline 5. & Goksura $^{12}$ & Goksura & $\begin{array}{l}\text { Tribulus terrestries } \\
\text { Linn. }\end{array}$ & Zygophyllaceae & $\begin{array}{l}\text { Swadukantaka, Trikantaka, } \\
\text { Channdrum }\end{array}$ \\
\hline 6. & $\begin{array}{l}\text { Khurasani } \\
\text { Ajvayna }^{13}\end{array}$ & $\begin{array}{l}\text { Parsheek Ya- } \\
\text { vani }\end{array}$ & $\begin{array}{l}\text { Hyoscyamus niger } \\
\text { Linn. }\end{array}$ & Solanaceae & Yavani, turuska, madkarini. \\
\hline 7. & $\begin{array}{l}\text { Rakta Chan- } \\
\text { dan }^{14}\end{array}$ & Rakt Chandan & $\begin{array}{l}\text { Pterocarpus santali- } \\
\text { nus Linn. }\end{array}$ & Leguminosae & Lal Chandan, Red Senders \\
\hline 8. & Anantmoola 15 & Sariva & $\begin{array}{l}\text { Hemidesmus indicus } \\
\text { R.Br. }\end{array}$ & Asclepiadaceae & $\begin{array}{l}\text { Utpalsariva, Gopvalli, Indian Sar- } \\
\text { saparita }\end{array}$ \\
\hline 9. & Sounf $f^{16}$ & Mishriya & $\begin{array}{l}\text { Foenieulum vulgare } \\
\text { Mill. }\end{array}$ & Umbelliferae & Madhurika, Misi, Madura \\
\hline 10. & Dhaniya $^{17}$ & Dhanyaka & $\begin{array}{l}\text { Coriandrum sativum } \\
\text { Linn. }\end{array}$ & Umbelliferae & Chatra, Vitunnika, Kustumbaru \\
\hline 11. & $\operatorname{Sogaan}^{18}$ & Shak & Tectona grandis Linn. & Verbenaceae & $\begin{array}{l}\text { Sthirsaar, Sogaan, Sagwan, Teak } \\
\text { tree }\end{array}$ \\
\hline
\end{tabular}




\begin{tabular}{|c|c|c|c|c|c|}
\hline 12. & Makoye $^{19}$ & Kakmachi & $\begin{array}{l}\text { Solanum nigrum } \\
\text { Linn. }\end{array}$ & Solanaceae & $\begin{array}{l}\text { Kakmachi, Makoye, Black night } \\
\text { shade }\end{array}$ \\
\hline 13. & Kasani $^{20}$ & Kasani & $\begin{array}{l}\text { Cichorium intybus } \\
\text { Linn. }\end{array}$ & Compositae & Hinduba, Chicory \\
\hline 14. & Khira $^{21}$ & Tripusha & Cucumis sativus Linn. & Cucurbitaceae & Khira, Cucumber \\
\hline 15. & Giloy $^{22}$ & Guduchi & $\begin{array}{l}\text { Tinospora cordifolia } \\
\text { (Willd.) }\end{array}$ & Menispermaceae & $\begin{array}{l}\text { Madhuparni, Amrita, Chinnruha, } \\
\text { Tantrika. }\end{array}$ \\
\hline 16. & Pashanbhed ${ }^{23}$ & Pashanbhed & $\begin{array}{l}\text { Bergenis ligulata } \\
\text { ((Wall.) Engl.) }\end{array}$ & Saxifragaceae & $\begin{array}{l}\text { Asmghna, Pakhaanbhed, Shil- } \\
\text { phada, Patharchat }\end{array}$ \\
\hline 17. & Kamal $^{24}$ & Padam & $\begin{array}{l}\text { Nelumbium specio- } \\
\text { sum Willd. }\end{array}$ & Nymphaeaceae & Mahautpala, Satpatra, Arvind \\
\hline 18. & Kaknaj $^{25}$ & Rajaputrika & $\begin{array}{l}\text { Physalis alkekengi } \\
\text { Linn. }\end{array}$ & Solonaceae & $\begin{array}{l}\text { Bladder -cherry, Ground-cherry, } \\
\text { Winter-cherry }\end{array}$ \\
\hline
\end{tabular}

Action \& properties of some Ayurvedic Dravyas working on Mutraveha Strotas

\begin{tabular}{|c|c|c|c|c|c|c|c|}
\hline $\begin{array}{l}\text { S. } \\
\text { No }\end{array}$ & Dravya & Rasa & Guna & Virya & Vipaka & $\begin{array}{l}\text { Dosh- } \\
\text { Karma }\end{array}$ & Anyakarma \\
\hline 1. & Punarnava ${ }^{26}$ & $\begin{array}{l}\text { Madhura, } \\
\text { Tikta, Kasaya }\end{array}$ & $\begin{array}{l}\text { Laghu, } \\
\text { Ruksha }\end{array}$ & Usna & Madhura & $\begin{array}{l}\text { Tridosh- } \\
\text { hara }\end{array}$ & $\begin{array}{l}\text { Shoth-hara, Mutrajana, Ra- } \\
\text { sayana }\end{array}$ \\
\hline 2. & $I k s h u^{27}$ & Madhura & $\begin{array}{l}\text { Guru, } \\
\text { Snigdha }\end{array}$ & Sheeta & Madhura & $\begin{array}{l}\text { Vata-Pitta- } \\
\text { Shamaka }\end{array}$ & Mutral \\
\hline 3. & Kusha ${ }^{28}$ & $\begin{array}{l}\text { Madhura, } \\
\text { Kasaya }\end{array}$ & $\begin{array}{l}\text { Laghu, } \\
\text { Snigdha }\end{array}$ & Sheeta & Madhura & $\begin{array}{l}\text { Vata-Pitta- } \\
\text { Shamaka }\end{array}$ & $\begin{array}{lr}\text { Mutavirechneeya, } & \text { Ash- } \\
\text { maribhedana, } & \text { Dahasa- } \\
\text { maka, Shulahara } & \end{array}$ \\
\hline 4. & Kasa $^{29}$ & $\begin{array}{l}\text { Madhura, } \\
\text { Kasaya }\end{array}$ & $\begin{array}{l}\text { Laghu, } \\
\text { Snigdha }\end{array}$ & Sheeta & Madhura & $\begin{array}{l}\text { Tridosh- } \\
\text { hara }\end{array}$ & $\begin{array}{l}\text { Ashmarinashna, Mutral, } \\
\text { Dahaprashmna }\end{array}$ \\
\hline 5. & Goksur $^{30}$ & Madhura & $\begin{array}{l}\text { Guru, } \\
\text { Snigdha }\end{array}$ & Sheeta & Madhura & $\begin{array}{l}\text { Vata-Pitta- } \\
\text { Shamaka }\end{array}$ & $\begin{array}{l}\text { Anulomana, Vednasthap- } \\
\text { ana, Balya, Mutral, Ash- } \\
\text { marinashana }\end{array}$ \\
\hline 6. & $\begin{array}{l}\text { Khurasani } \\
\text { Ajvayna }^{31}\end{array}$ & Tikta, Katu & Ruksha & Usna & Katu & $\begin{array}{l}\text { Kapha-Vata- } \\
\text { Shamaka }\end{array}$ & $\begin{array}{lr}\text { Shoth-hara, } & \text { Ash- } \\
\text { maribhedanqa, } & \text { Madaka, } \\
\text { Vednasthapaka } & \end{array}$ \\
\hline 7. & $\begin{array}{l}\text { Rakta Chan- } \\
\text { dan }^{32}\end{array}$ & $\begin{array}{l}\text { Tikta, } \\
\text { Madhura }\end{array}$ & $\begin{array}{l}\text { Guru, } \\
\text { Ruksha }\end{array}$ & Sheeta & Madhura & $\begin{array}{l}\text { Kapha- } \\
\text { Pitta-Sa- } \\
\text { maka }\end{array}$ & Dahashamaka, Shoth-hara \\
\hline 8. & Anantmoola ${ }^{33}$ & $\begin{array}{l}\text { Madhura, } \\
\text { Tikta }\end{array}$ & $\begin{array}{l}\text { Guru, } \\
\text { Snigdha }\end{array}$ & Sheeta & Madhura & $\begin{array}{l}\text { Tridosh- } \\
\text { hara }\end{array}$ & $\begin{array}{ll}\text { Dahashamaka, } & \text { Shoth-hara, } \\
\text { Mutrajana, } & \text { Mutrvirech- } \\
\text { neeya } & \end{array}$ \\
\hline 9. & Sounf ${ }^{34}$ & $\begin{array}{l}\text { Madura, } \\
\text { Katu, Tikta }\end{array}$ & $\begin{array}{l}\text { Laghu, } \\
\text { Snigdha }\end{array}$ & Sheeta & Madhura & $\begin{array}{l}\text { Vatapit- } \\
\text { tashamaka }\end{array}$ & Mutral, Dahaprashmana \\
\hline 10. & Dhanyaka $^{35}$ & $\begin{array}{l}\text { Kasaya, } \\
\text { Tikta, } \\
\text { Madhura, } \\
\text { Katu }\end{array}$ & $\begin{array}{l}\text { Laghu, } \\
\text { Snigdha }\end{array}$ & Usna & Madhura & $\begin{array}{l}\text { Tridosh- } \\
\text { hara }\end{array}$ & Mutrajana, Mutrvirjneeya \\
\hline 11. & Sogaan ${ }^{36}$ & Kasaya & $\begin{array}{l}\text { Laghu, } \\
\text { Ruksha }\end{array}$ & Sheeta & Katu & $\begin{array}{l}\text { Kapha- } \\
\text { Pitta-Sa- } \\
\text { maka }\end{array}$ & $\begin{array}{l}\text { Shoth-hara, } \\
\text { Vednasthapaka, Mutrajana } \\
\text { (Beej), Mutrastambhana } \\
\text { (Chal) }\end{array}$ \\
\hline
\end{tabular}




\begin{tabular}{|c|c|c|c|c|c|c|c|}
\hline 12. & Makoye ${ }^{37}$ & Tikta & $\begin{array}{l}\text { Laghu, } \\
\text { Snigdha }\end{array}$ & Anushna & Katu & $\begin{array}{l}\text { Tridosh- } \\
\text { hara }\end{array}$ & $\begin{array}{l}\text { Shoth-hara, } \\
\text { Vednasthapaka, Mutral }\end{array}$ \\
\hline 13. & Kasani $^{38}$ & Tikta & $\begin{array}{l}\text { Laghu, } \\
\text { Ruksha }\end{array}$ & Usna & Katu & $\begin{array}{l}\text { Kaphapit- } \\
\text { tasamaka }\end{array}$ & $\begin{array}{l}\text { Dahaprashmana, Shoth- } \\
\text { hara, Mutral }\end{array}$ \\
\hline 14. & Khira ${ }^{39}$ & Madhura & $\begin{array}{l}\text { Laghu, } \\
\text { Ruksha }\end{array}$ & Sheeta & Madhura & $\begin{array}{l}\text { Pit- } \\
\text { tashamaka }\end{array}$ & Dahaprashmana, Mutral \\
\hline 15. & Giloy ${ }^{40}$ & Tikta, Kasaya & $\begin{array}{l}\text { Guru, } \\
\text { Snigdha }\end{array}$ & Usna & Madhura & $\begin{array}{l}\text { Tridosh- } \\
\text { hara }\end{array}$ & Vednasthapana, Rasayana \\
\hline 16. & Pashanbhed $^{41}$ & Kasaya, Tikta & $\begin{array}{l}\text { Laghu, } \\
\text { Snigdha, } \\
\text { Tikshna }\end{array}$ & Sheeta & Katu & $\begin{array}{l}\text { Tridosh- } \\
\text { hara }\end{array}$ & $\begin{array}{l}\text { Shoth-hara, Ash- } \\
\text { maribhedanqa, Mutral }\end{array}$ \\
\hline 17. & Kamal $^{42}$ & $\begin{array}{l}\text { Madhura, La- } \\
\text { vana }\end{array}$ & Ruksha & Sheeta & Guru & $\begin{array}{l}\text { Kaphapit- } \\
\text { tasamaka }\end{array}$ & $\begin{array}{l}\text { Dahaprashmana, Mutravi- } \\
\text { rechneeya, Mutravirjneeya }\end{array}$ \\
\hline 18. & Kaknaj $^{43}$ & $\begin{array}{l}\text { Madhura, } \\
\text { Tikta }\end{array}$ & Ruksha & Sheeta & Katu & Vatahara, & $\begin{array}{l}\text { Balya, Mutrala, Dahasa- } \\
\text { maka, Sulanasini, }\end{array}$ \\
\hline
\end{tabular}

\section{DISCUSSION}

Strotas $^{44}$ are known to be the channels of our body system which connects the whole-body system. Also, it helps in nourishment, cleansing, homeostasis of the body. There are about $22^{45}$ types of Strotas present in our body for performing different body functions. Mutraveha Strotas are one of them. They are related to the urinary system of the body. Conditions like Mutrakricha, Mutradaha, Mutraghata, Ashmari, Mutraalpta, Prameha etc can be treated through drugs acting on Mutraveha Strotas. As per modern perspectives, we all know that $85 \%$ of homeostasis is done by kidneys themselves. Also, hormonal imbalance is caused by dysfunctions of these Strotas in the body. Mutraveha Strotas are the channels that help in the functioning of the whole urinary system ${ }^{46}$. These channels help in the absorption, cleansing, and excretion process done by multiple organs of the urinary system. In the urinary system, major work is done by both the kidneys. They accept the Rasa, absorbs nutritive substance from that, a filter that, then excrete that matter. Then both the Ureters provide a pathway for urine and help its storage in the urinary bladder, bladder stored urine for some time then the maturation process start, and it gets out of the body through the urethra. So, by these multiple organs works on this and all these organs work with the help ho these channels. Because we are analyzing Mutraveha Strotas here, so we have to know about the composition of Mutra as per
Ayurveda. Mutra is a composition of Jala and Agni Guna Pradhana majorly ${ }^{47}$. Jala is the base of urine; Agni Mahabhuta is responsible for increasing the blood pressure within the Glomeruli and irritation in kidneys for the micturition process ${ }^{48}$. Vayu Mahabhuta is responsible for the exploitation of water also is responsible for the motion and removes all the blockages ${ }^{49}$. Akasha-Prithvi-Mahabhuta helps in proper absorption of useful substance through Mutraveha Strotas also it gives space to the Dosha for movements; also, they help in excretion process ${ }^{50}$. As are all the Dravyas mainly dominating Jala, Agni \& Vayu Mahabuta. So, by their properties, they can help in treating multiple urinary disorders like Mutrkrichha, Sotha, Raktamutrata, Ashmari, Sula etc. Some modern Ayurvedic authors also suggest that Ayurvedic treatment is far better for the cure and prevention of any disease condition. A book named "Advances in Ayurvedic Medicine - Diseases of Kidney \& Urinary Tract" ${ }^{\prime 1}$ states that the kidneys have a marked capacity for regeneration. In pathological conditions the kidney regenerates only in stages where there is only cellular damage \& renal architecture and the supporting structures are not distorted, provided there is an adequate increase in physiological demand on the kidney due to massive disease. Also, they use Ayurvedic drug for their trial and prove that Punarnava is working on Urinary System and give efficient results. Drugs like Punarnava ${ }^{52}, I k s h u^{53}, k u s h a^{54}$ and all the 
drugs listed in this article are effective in urinary disorders. Many researchers mentioned their efficacy in their work.

\section{CONCLUSION}

As we know we have a vast range of treatments related to dysfunction of the urinary system organ. As modern science said these infections can occur due to the manifestation of a special type of microorganisms usually bacteria. These bacteria enter the urethra then the bladder and cause inflammation and infection ${ }^{55}$. We use different types of anti-fungal/anti-bacterial drugs to get rid of these infections; initially, these drugs treat the condition but not really in a proper manner. As per Ayurveda, any type of disease condition occurs due to Mithya Aahaar-Vihaar which increases the chances of disease manifestation in the body. For the treatment protocol, the primary treatment theory given by the Ayurvedacharya's is to follow a proper diet regimen according to your Prakriti \& Ritu. If the condition is not treated with changing lifestyle, then Acharyas suggests, going with medicinal treatment. If someone having Ayurvedic treating he/she will get rid of diseased condition without any side effect because Ayurvedic drugs not only treated the disease but also, they provide nourishment and nutrient to the body. In today's era, there is a wide range of people suffering from an unhealthy urinary system due to renal calculi, burning micturition, urinary tract infection, pelvic inflammatory disorders are most common. In chronic conditions, people are forced to depend on machinery for cleansing their system for one of the common examples is dialysis. Dialysis is one of the common processes which could be done for the removal of waste products and excessive fluid from the body when kidneys stop working. It is somewhere costly not everyone can afford it. Also, it has some side effect on the body system of the patient. Ayurveda gives you the perfect solution for every diseased condition. The drugs we listed in this article having properties like Shothahara, Vednasthapana, Prabhava like Ashmaribhedana, Vata-Pitta-hara; some of them are Rasayana Dravya which helps in rejuvenating the body cells and helps in properly maintain health also buildup the immunity and control the reoccurrence of diseases. Also, these drugs are good for urinary system health. Hence, we can advise these drugs for the preventative treatment of urinary tract infections either single or can be used as combined formulation.

\section{REFERENCES}

1. Charaka Samhita of Agnivesha revised by Caraka \& Drdhbala with an introduction by Vaidya Samarata, Sri Satya Narayana Sastri`Padambhusana' which elaborated Vidyotini Hindi Commentary by Pt. Kasinath Sastri, Dr Grakhanath Chaturvedi, Purvadha, Vimanasathana, reprint edition-2020, Chaukhambha Bharati Academy, Varanasi, p- 633.

2. Charaka Samhita of Agnivesha revised by Caraka \& Drdhbala with an introduction by Vaidya Samarata, Sri Satya Narayana Sastri`Padambhusana’ which elaborated Vidyotini Hindi Commentary by Pt. Kasinath Sastri, Dr Grakhanath Chaturvedi, Purvadha, Sutrasathana, reprint edition-1998, Chaukhambha Bharati Academy, Varanasi, p-89.

3. Charaka Samhita of Agnivesha revised by Caraka \& Drdhbala with an introduction by Vaidya Samarata, Sri Satya Narayana Sastri‘Padambhusana' which elaborated Vidyotini Hindi Commentary by Pt. Kasinath Sastri, Dr Grakhanath Chaturvedi, Purvadha, Sutrasathana, reprint edition-1998, Chaukhambha Bharati Academy, Varanasi, p-89.

4. Charaka Samhita of Agnivesha revised by Caraka \& Drdhbala with an introduction by Vaidya Samarata, Sri Satya Narayana Sastri‘Padambhusana' which elaborated Vidyotini Hindi Commentary by Pt. Kasinath Sastri, Dr Grakhanath Chaturvedi, Purvadha, Sutrasathana, reprint edition-1998, Chaukhambha Bharati Academy, Varanasi, p-89.

5. Dravyaguna Hastamlaka, forwarded by Shri Vishwanath Diwedi by Vaidya Banwari Lal Mishra, edited by Vaidya Santosh Kumar Sharma" Khandal", reprint edition 2006, Publication Scheme, Jaipur, p119.

6. Charaka Samhita of Agnivesha revised by Caraka \& Drdhbala with an introduction by Vaidya Samarata, Sri Satya Narayana Sastri'Padambhusana' which elaborated Vidyotini Hindi Commentary by Pt. Kasinath Sastri, Dr Grakhanath Chaturvedi, Purvadha, Sutrasathana, reprint edition-2020, Chaukhambha Bharati Academy, Varanasi, p-83 
7. Dravyaguna Hastamlaka, forwarded by Shri Vishwanath Diwedi by Vaidya Banwari Lal Mishra, edited by Vaidya Santosh Kumar Sharma" Khandal", reprint edition 2006, Publication Scheme, Jaipur, p-99

8. BhavprakashNighantu, Guduchiyadi Varga, by ShriBhavaMisra; Edited with the "Vidyotini" Hindi commentary Notes and Appendix by ShriBrahmasankaraMisra and ShriRupalalajiVaisya; First part; edition $8^{\text {th }}, 1997$; Chaukhambha Sanskrit Sansthana, Varanasi, $\mathrm{p}-425$.

9. BhavprakashNighantu, Ikshu Varga, by ShriBhavaMisra; Edited with the "Vidyotini" Hindi commentary Notes and Appendix by ShriBrahmasankaraMisra and ShriRupalalajiVaisya; First part; edition $8^{\text {th }}, 1997$; Chaukhambha Sanskrit Sansthana, Varanasi, p-792.

10. BhavprakashNighantu, Guduchiyadi Varga, by ShriBhavaMisra; Edited with the "Vidyotini" Hindi commentary Notes and Appendix by ShriBrahmasankaraMisra and ShriRupalalajiVaisya; First part; edition $8^{\text {th }}$, 1997; Chaukhambha Sanskrit Sansthana, Varanasi, p-380.

11. BhavprakashNighantu, Guduchiyadi Varga, by ShriBhavaMisra; Edited with the "Vidyotini" Hindi commentary Notes and Appendix by ShriBrahmasankaraMisra and ShriRupalalajiVaisya; First part; edition $8^{\text {th }}, 1997$; Chaukhambha Sanskrit Sansthana, Varanasi, p-382.

12. BhavprakashNighantu, Guduchiyadi Varga, by ShriBhavaMisra; Edited with the "Vidyotini" Hindi commentary Notes and Appendix by ShriBrahmasankaraMisra and ShriRupalalajiVaisya; First part; edition $8^{\text {th }}, 1997$; Chaukhambha Sanskrit Sansthana, Varanasi, p-292.

13. BhavprakashNighantu, Haritkyadi Varga, by ShriBhavaMisra; Edited with the "Vidyotini" Hindi commentary Notes and Appendix by ShriBrahmasankaraMisra and ShriRupalalajiVaisya; First part; edition $8^{\text {th }}$, 1997; Chaukhambha Sanskrit Sansthana, Varanasi, p-29.

14. BhavprakashNighantu, Karpuradi Varga, by ShriBhavaMisra; Edited with the "Vidyotini" Hindi commentary Notes and Appendix by ShriBrahmasankaraMisra and ShriRupalalajiVaisya; First part; edition $8^{\text {th }}, 1997$; Chaukhambha Sanskrit Sansthana, Varanasi, p-191.

15. BhavprakashNighantu, Guduchiyadi Varga, by ShriBhavaMisra; Edited with the "Vidyotini" Hindi commentary Notes and Appendix by ShriBrahmasankaraMisra and ShriRupalalajiVaisya; First part; edition $8^{\text {th }}$, 1997; Chaukhambha Sanskrit Sansthana, Varanasi, p-427.
16. BhavprakashNighantu, haritkiyadi Varga, by ShriBhavaMisra; Edited with the "Vidyotini" Hindi commentary Notes and Appendix by ShriBrahmasankaraMisra and ShriRupalalajiVaisya; First part; edition $8^{\text {th }}, 1997$; Chaukhambha Sanskrit Sansthana, Varanasi, p-36.

17. BhavprakashNighantu, Haritkiyadi Varga, by ShriBhavaMisra; Edited with the "Vidyotini" Hindi commentary Notes and Appendix by ShriBrahmasankaraMisra and ShriRupalalajiVaisya; First part; edition $8^{\text {th }}, 1997$; Chaukhambha Sanskrit Sansthana, Varanasi, p-34.

18. BhavprakashNighantu, Vataadi Varga, by ShriBhavaMisra; Edited with the "Vidyotini" Hindi commentary Notes and Appendix by ShriBrahmasankaraMisra and ShriRupalalajiVaisya; First part; edition $8^{\text {th }}, 1997$; Chaukhambha Sanskrit Sansthana, Varanasi, p-549.

19. BhavprakashNighantu, Guduchiyadi Varga, by ShriBhavaMisra; Edited with the "Vidyotini" Hindi commentary Notes and Appendix by ShriBrahmasankaraMisra and ShriRupalalajiVaisya; First part; edition $8^{\text {th }}$, 1997; Chaukhambha Sanskrit Sansthana, Varanasi, p-438.

20. Dravyaguna Hastamlaka, forwarded by shri Vishwanath Diwedi by Vaidya Banwari Lal Mishra, edited by Vaidya Santosh Kumar Sharma" Khandal", reprint edition 2006, Publication Scheme, Jaipur, p300.

21. BhavprakashNighantu, Amradi Varga, by ShriBhavaMisra; Edited with the "Vidyotini" Hindi commentary Notes and Appendix by ShriBrahmasankaraMisra and ShriRupalalajiVaisya; First part; edition $8^{\text {th }}, 1997$; Chaukhambha Sanskrit Sansthana, Varanasi, p-562.

22. BhavprakashNighantu, Guduchiyadi Varga, by ShriBhavaMisra; Edited with the "Vidyotini" Hindi commentary Notes and Appendix by ShriBrahmasankaraMisra and ShriRupalalajiVaisya; First part; edition $8^{\text {th }}, 1997$; Chaukhambha Sanskrit Sansthana, Varanasi, p-269.

23. Dravyaguna Hastamlaka, forwarded by shri Vishwanath Diwedi by Vaidya Banwari Lal Mishra, edited by Vaidya Santosh Kumar Sharma" Khandal", reprint edition 2006, Publication Scheme, Jaipur, p454.

24. BhavprakashNighantu, Pushpa Varga, by ShriBhavaMisra; Edited with the "Vidyotini" Hindi commentary Notes and Appendix by ShriBrahmasankaraMisra and ShriRupalalajiVaisya; First part; edition $8^{\text {th }}, 1997$; Chaukhambha Sanskrit Sansthana, Varanasi, p-470. 
25. https://entranceindia.com/medicinal-plants-herbsflowers/kakanaja-fruit-in-ayurveda-botanical-namephysalis-alkekengi-linn/

26. BhavprakashNighantu, Guduchiyadi Varga, by ShriBhavaMisra; Edited with the "Vidyotini" Hindi commentary Notes and Appendix by ShriBrahmasankaraMisra and ShriRupalalajiVaisya; First part; edition $8^{\text {th }}, 1997$; Chaukhambha Sanskrit Sansthana, Varanasi, $\mathrm{p}-425$.

27. BhavprakashNighantu, Ikshu Varga, by ShriBhavaMisra; Edited with the "Vidyotini" Hindi commentary Notes and Appendix by ShriBrahmasankaraMisra and ShriRupalalajiVaisya; First part; edition $8^{\text {th }}$, 1997; Chaukhambha Sanskrit Sansthana, Varanasi, p-792.

28. BhavprakashNighantu, Guduchiyadi Varga, by ShriBhavaMisra; Edited with the "Vidyotini" Hindi commentary Notes and Appendix by ShriBrahmasankaraMisra and ShriRupalalajiVaisya; First part; edition $8^{\text {th }}$, 1997; Chaukhambha Sanskrit Sansthana, Varanasi, p-380.

29. BhavprakashNighantu, Guduchiyadi Varga, by ShriBhavaMisra; Edited with the "Vidyotini" Hindi commentary Notes and Appendix by ShriBrahmasankaraMisra and ShriRupalalajiVaisya; First part; edition $8^{\text {th }}, 1997$; Chaukhambha Sanskrit Sansthana, Varanasi, p-382.

30. BhavprakashNighantu, Guduchiyadi Varga, by ShriBhavaMisra; Edited with the "Vidyotini" Hindi commentary Notes and Appendix by ShriBrahmasankaraMisra and ShriRupalalajiVaisya; First part; edition $8^{\text {th }}$, 1997; Chaukhambha Sanskrit Sansthana, Varanasi, p-292.

31. BhavprakashNighantu, Haritkyadi Varga, by ShriBhavaMisra; Edited with the "Vidyotini" Hindi commentary Notes and Appendix by ShriBrahmasankaraMisra and ShriRupalalajiVaisya; First part; edition $8^{\text {th }}$, 1997; Chaukhambha Sanskrit Sansthana, Varanasi, p-29.

32. BhavprakashNighantu, Karpuradi Varga, by ShriBhavaMisra; Edited with the "Vidyotini" Hindi commentary Notes and Appendix by ShriBrahmasankaraMisra and ShriRupalalajiVaisya; First part; edition $8^{\text {th }}, 1997$; Chaukhambha Sanskrit Sansthana, Varanasi, p-191.

33. BhavprakashNighantu, Guduchiyadi Varga, by ShriBhavaMisra; Edited with the "Vidyotini" Hindi commentary Notes and Appendix by ShriBrahmasankaraMisra and ShriRupalalajiVaisya; First part; edition $8^{\text {th }}$, 1997; Chaukhambha Sanskrit Sansthana, Varanasi, p-427.
34. BhavprakashNighantu, haritkiyadi Varga, by ShriBhavaMisra; Edited with the "Vidyotini" Hindi commentary Notes and Appendix by ShriBrahmasankaraMisra and ShriRupalalajiVaisya; First part; edition $8^{\text {th }}, 1997$; Chaukhambha Sanskrit Sansthana, Varanasi, p-36.

35. BhavprakashNighantu, Haritkiyadi Varga, by ShriBhavaMisra; Edited with the "Vidyotini" Hindi commentary Notes and Appendix by ShriBrahmasankaraMisra and ShriRupalalajiVaisya; First part; edition $8^{\text {th }}, 1997$; Chaukhambha Sanskrit Sansthana, Varanasi, p-34.

36. BhavprakashNighantu, Vataadi Varga, by ShriBhavaMisra; Edited with the "Vidyotini" Hindi commentary Notes and Appendix by ShriBrahmasankaraMisra and ShriRupalalajiVaisya; First part; edition $8^{\text {th }}, 1997$; Chaukhambha Sanskrit Sansthana, Varanasi, p-549.

37. BhavprakashNighantu, Guduchiyadi Varga, by ShriBhavaMisra; Edited with the "Vidyotini" Hindi commentary Notes and Appendix by ShriBrahmasankaraMisra and ShriRupalalajiVaisya; First part; edition $8^{\text {th }}$, 1997; Chaukhambha Sanskrit Sansthana, Varanasi, p-438.

38. Dravyaguna Hastamlaka, forwarded by shri Vishwanath Diwedi by Vaidya Banwari Lal Mishra, edited by Vaidya Santosh Kumar Sharma"Khandal", reprint edition 2006, Publication Scheme, Jaipur, p300.

39. BhavprakashNighantu, Amradi Varga, by ShriBhavaMisra; Edited with the "Vidyotini" Hindi commentary Notes and Appendix by ShriBrahmasankaraMisra and ShriRupalalajiVaisya; First part; edition $8^{\text {th }}$, 1997; Chaukhambha Sanskrit Sansthana, Varanasi, p-562.

40. BhavprakashNighantu, Guduchiyadi Varga, by ShriBhavaMisra; Edited with the "Vidyotini" Hindi commentary Notes and Appendix by ShriBrahmasankaraMisra and ShriRupalalajiVaisya; First part; edition $8^{\text {th }}$, 1997; Chaukhambha Sanskrit Sansthana, Varanasi, p-269.

41. Dravyaguna Hastamlaka, forwarded by shri Vishwanath Diwedi by Vaidya Banwari Lal Mishra, edited by Vaidya Santosh Kumar Sharma"Khandal", reprint edition 2006, Publication Scheme, Jaipur, p454.

42. BhavprakashNighantu, Pushpa Varga, by ShriBhavaMisra; Edited with the "Vidyotini" Hindi commentary Notes and Appendix by ShriBrahmasankaraMisra and ShriRupalalajiVaisya; First part; edition $8^{\text {th }}, 1997$; Chaukhambha Sanskrit Sansthana, Varanasi, p-470. 
43. https://entranceindia.com/medicinal-plants-herbsflowers/kakanaja-fruit-in-ayurveda-botanical-namephysalis-alkekengi-linn/

44. Charaka Samhita of Agnivesha revised by Caraka \& Drdhbala with an introduction by Vaidya Samarata, Sri Satya Narayana Sastri'Padambhusana’ which elaborated Vidyotini Hindi Commentary by Pt. Kasinath Sastri, Dr Grakhanath Chaturvedi, Purvadha, Vimanasathana, reprint edition-2020, Chaukhambha Bharati Academy, Varanasi, p- 631.

45. Charaka Samhita of Agnivesha revised by Caraka \& Drdhbala with an introduction by Vaidya Samarata, Sri Satya Narayana Sastri‘Padambhusana' which elaborated Vidyotini Hindi Commentary by Pt. Kasinath Sastri, Dr Grakhanath Chaturvedi, Purvadha, Vimanasathana, reprint edition-2020, Chaukhambha Bharati Academy, Varanasi, p- 632.

46. https://www.easyayurveda.com/2016/06/02/srotasbody-channels-and-duct-systems-of-body/

47. Charaka Samhita of Agnivesha revised by Caraka \& Drdhbala with an introduction by Vaidya Samarata, Sri Satya Narayana Sastri'Padambhusana' which elaborated Vidyotini Hindi Commentary by Pt. Kasinath Sastri, Dr Grakhanath Chaturvedi, Purvadha, Sutrasathana, reprint edition-1998, Chaukhambha Bharati Academy, Varanasi, p-89.

48. Charaka Samhita of Agnivesha revised by Caraka \& Drdhbala with an introduction by Vaidya Samarata, Sri Satya Narayana Sastri'Padambhusana' which elaborated Vidyotini Hindi Commentary by Pt. Kasinath Sastri, Dr Grakhanath Chaturvedi, Purvadha, Sutrasathana, reprint edition-1998, Chaukhambha Bharati Academy, Varanasi, p-89.

49. Charaka Samhita of Agnivesha revised by Caraka \& Drdhbala with an introduction by Vaidya Samarata, Sri Satya Narayana Sastri 'Padambhusana' which elaborated Vidyotini Hindi Commentary by Pt. Kasinath Sastri, Dr Grakhanath Chaturvedi, Purvadha, Sutrasathana, reprint edition-1998, Chaukhambha Bharati Academy, Varanasi, p-90.

50. Charaka Samhita of Agnivesha revised by Caraka \& Drdhbala with an introduction by Vaidya Samarata, Sri Satya Narayana Sastri'Padambhusana' which elaborated Vidyotini Hindi Commentary by Pt. Kasinath Sastri, Dr Grakhanath Chaturvedi, Purvadha, Sutrasathana, reprint edition-1998, Chaukhambha Bharati Academy, Varanasi, p-90.

51. Advances in Ayurvedic Medicine - Diseases of Kidney \& Urinary Tract, by Prof. R.H. Singh \& Prof.
K.N.Udupa, Volume I, First edition 2005, Chaukhambha Vishvabharati, Varanasi, p-237.

52. https://www.ncbi.nlm.nih.gov/pmc/articles/PMC2964762/

53. https://www.ijhsr.org/IJHSR_Vol.7_Issue.9_Sep2017/48.pdf

54. http://jddtonline.info/index.php/jddt/article/view/1853/1305

55. https://my.clevelandclinic.org/health/diseases/9135urinary-tract-infections

\section{Source of Support: Nil Conflict of Interest: None Declared}

How to cite this URL: Ritu \& Kulbhushan: A Review Article On The Efficacy Of Ayurvedic Drugs In The Management Of Mutraveha Strotas. International Ayurvedic Medical Journal \{online\} 2021 \{cited September 2021\} Available from: http://www.iamj.in/posts/images/upload/2105_2112.pdf 